\title{
Potrait of Social Interaction among the Vilagers in the Perspective of George Herbet Mead's Symbolic Interactionalism Theory
}

\author{
Ari Rohmawati ${ }^{1}$, Meiwatizal Trihastuti ${ }^{2}$, Anis Suryaningsih ${ }^{3}$, Habib Ismail ${ }^{4}$ \\ ,1,4Institut Agama Islam Ma'arif NU Metro Lampung, Indonesia \\ 2STKIP Pasundan Cimahi, Indonesia \\ 3Universitas Sebelas Maret Surakarta, Indonesia
}

rrhmwt91@gmail.com

\begin{abstract}
The aim of this study was to know how the portrait of social interactions that occur between villagers in the Perspective of George Herbet Mead's symbolic intercationalism theory and to determine the factors that support social interaction between villagers. This article was descriptive qualitative. The researchers used documentation, observation and interviews in collecting the data. The result show that The form of social interaction that occurs between Restu Buana villagers and Bumi Nabung Ilir village residents is in the form of associative-cooperation (in the form of trade / buying and selling between villagers, friendship)/ Second, it is in the form of associative-accommodation (that is, in the event of a fight, usually with mediation by leaders religious. Third, the form of dissociation f-Contravention which is manifested by the feeling of resentment. Fourth, which is in the form of dissociative-competition such as competition in the economy. Factors that support social interaction: first, there is mutual tolerance between residents. Thirdly their mutual appreciation of cultures of other villagers.
\end{abstract}

ARTICLE INFO

Article history:

Received

January 17, 2021

Revised

March 03, 2021

Accepted

March 14, 2021

How to cite

Journal Homepage This is an open access article under the CC BY SA licens

Keywords: Social Interaction, Symbolic Interactionalism Theory, Goerge Herbet Mead's Symbolic

Rohmawati, A., Trihastuti, M., Suryaningsih, A \& Ismail, H. (2021). Potrait of Social Interaction among the Vilagers in the Perspective of George Herbet Mead's Symbolic Interactionalism Theory. IJoASER (International Journal on Advanced Science, Education, and Religion), 4(1).41-49

https://doi.org/10.33648/ijoaser.v4i1.94

https:/ /ojs.staialfurqan.ac.id/IJoASER/

https://creativecommons.org/licenses/by-sa/4.0/

\section{INTRODUCTION}

Humans are ontologically social creatures, requiring interaction between one person and another, as well as with his group. This concept is an An-Nas concept. The concept of Al-Nas tends to refer to the status and function of humans in relation to the surrounding community (Muhammad Kosim, 2012). The social interactions that occur between residents in Rumbia sub-district can also be said to be unique. People usually sort out who they relate to. This is due to the very diverse cultural differences in this sub-district, thus making their relationship possible from this difference the interaction relationship is more intimate for residents who really appreciate culture and think that differences will strengthen a relationship because humans are perceived to always need something. new by learning other cultures outside the group. 
Balinese community was the big second community in their daily life, there is also in the northern part of the Bumi Nabung Ilir sub-district, Bumi Nabung subdistrict, which uses the Lampung language. The diversity of languages gives a different color to their daily interactions. The interaction that occurs is what then gives birth to a shared understanding of the symbols of each citizen in the social interaction of residents in the Rumbia District. The community in the Rumbia District there are differences in both language and intonation, likewise in the Bumi Nabung Ilir Village, Bumi Nabung District. Restu Buana Village, for example, has Balinese language users, which have a characteristic high and loud speaking tone, while other villages such as Binakarya Mandii village have a soft tone. And in the sub-district of Bumi Nabung Ilir, the Subdistrict of Bumi is saving the majority of people who use the Lampung language. The phenomenon of the existence of language differences and the characteristics of the people is in the villages in this sub-district. So that the social interactions that occur between several communities can be said to be more sorting (Interview Result, 2020). It was cause the cultural differences are not only in the form of differences in language, but also in the character of the people. The culture of the people in Rumbia sub-district is also different. Some influenced by the Javanese, Lampung, some by the Bugis, and others by the Madurese and Malay culture. Because this sub-district is not only influenced by one ethnicity, so there are often misunderstandings from one village to another when they interact.

Some of the previous studies, for instance Tamboeo, et al., (2016) show that there are factors that cause the interaction of housing community where the factors behind the occurrence of social interaction in the Ketintang Scenic Community are the congregational prayers at the Baitul Haq mosque, the presence of recitation, religious halaqah, social gathering, PKK, sports, Work devotion, the band together, the anniversary of Islamic holidays, religious gatherings race events commemorating the day kemerdeaan on before August 17. Other research Mustof, (2017) show that social interaction at Perumahan Alam Sejahtera Dedy Jaya, basically they were formed because of the result of social activity among inhabitants. After the writer searched and observed deeply, the results of the research showed that the social interaction that occurs between inhabitants was through some forms of social interactions and they were classified in the process of cooperation, competition, accommodation, and conflict. The implementation in the field of social interaction that occurred between people was very good and the course of activity also happened very well; as a result, the activities at Perumahan Alam Sejahtera Dedy different because analyse the deep phenomenon cultural of residents among villagers in the district Rumbia, Kelurahan Restu Buana and villagers of Bumi Nabung Ilir Village, Bumi Nabung District so that the interactions that occur can be carried out even though they are of different cultures. In addition, the researcher uses George Herbet Mead's symbolic intercationalism theory in analyzing the portrait of social interactions. The second research is Mughaniyah entitled "Religious Social Interaction between Ethnic Groups (Javanese, Madurese, Arabic) in the Ampel area of Surabaya". The results of this study only provide an overview of the social interaction of religion seeing only aspects of religious activities that shape social interactions that occur between ethnic groups (Javanese, Madurese, Arabic). Meanwhile, researchers studied Balinese and Lampung languagespeaking communities and social interactions between villagers in Rumbia District, Restu Buana Village and Bumi Nabung Ilir Village residents, Bumi Nabung District

From the above phenomena, the researcher feels interested in researching the social interactions that occur between villagers in Rumbia District, Restu Buana Village 
and residents of Bumi Nabung Ilir Village, Bumi Nabung District. Because in this district there is a phenomenon of complex cultural differences. So that, it was feel very interested in researching the social interactions between villagers. The aim of this study was to know how the portrait of social interactions that occur between villagers in the Perspective of George Herbet Mead's Symbolic Intercationalism Theory and to determine the factors that support social interaction between villagers

\section{METHOD}

This research was research descriptive qualitative which is research that intends to understand the phenomena experienced by research subjects such as behavior, perception, motivation, action, etc., in a holistic manner, and by means of descriptions in the form of words. -words and language specific context naturally (Moleong, 2009). It presents a detailed picture of a special situation, social setting, or relationship. Qualitative description simply refers to the identification of the distinguishing traits or characteristics of a group of people, objects, or events. The subjects of this research are villagers in Rumbia Subdistrict, Restu Buana Urban Village and residents of Bumi Nabung Ilir Village, Bumi Nabung District. Through purposive technique, the total sample of this study was 15 people. The researchers used documentation, observation and interviews in collecting the data. Interview activities were carried out with several informants such as residents of villagers in Rumbia District, Restu Buana Village and residents of Bumi Nabung Ilir Village, Bumi Nabung District. Interviews are conducted to obtain information about problems related to one particular subject or other people. Observation is done by observing, systematically recording the social symptoms under study. The technique begins with all available data from various sources that researchers obtain such as from interviews, observations, and documents written with field notes and data analysis. The next step is to make the data inductively, namely to conclude the theory from the data that has been collected, to describe the real conditions in the field or the object to be studied in the form of writing. This is based on the theories that are used as the basis for this research.

\section{RESULT AND DISCUSSION}

\section{Theory of Symbolic Interactionism}

The problem to be addressed in this study is about social interaction between villagers in Rumbia District, so that the researcher in this case uses a social definition paradigm in which this paradigm emphasizes the subjective meaning of social action. This paradigm also defines sociology as a science that seeks to interpret and understand a social action (Soerjono Soekanto, 2013). The theory used in this study is the theory of symbolic interaction, in which this theory argues that individuals are seen as actors who interpret, judge, define, and act. The reaction that occurs is not just a mere reaction, but from one's actions towards other people's actions based on "meaning". contained in these interactions (Ayustiani, et al., 2019). This theory also understands reality as a social interaction which is fulfilled as a symbol. The basic principles of symbolic interaction give the assumption that humans have the ability to think (Saputra, 2015). With this thinking ability possessed by humans, it is what distinguishes humans from animals. Thinking according to Mead is a process where individuals interact with themselves by using meaningful symbols (Abdullah \& Siti Nuralfia, 2020). Through the process of interaction with oneself, the individual chooses which of the stimuli aimed at him he will respond too (Yuliati, 2017). The symbol itself is something whose value or meaning is given to it according to the person using it. 
If the action that occurs in animals is only a stimulus-response, then social action that occurs in humans is not an action that only relies on the stimulus automatically or directly provides a response or response, but between the stimulus received and the response to be given is based on the existence of a process think of the human (Ilawatus, 2017). So that with this thinking process the individual chooses which of the stimuli aimed at him he will respond to. According to Mead, humans have a number of possible actions in their mind before taking the actual action, a person tries these various alternative actions mentally by considering his thoughts (Hikmah, 2017). Because actually in the human action process there is a closed mental process that precedes the actual action process in the form of actual or visible behavior. The capacity to think in humans will be formed through a process of social interaction, namely socialization (Derung , 2017). The human ability to think is formed in socialization during childhood and develops during socialization when becoming an adult (Ihsanudin, 2019). For symbolic interaction, socialization is dynamic in that in this process humans not only receive information but also interpret and adjust the information according to their needs. In carrying out social actions an individual usually takes into account other individuals and decides how to behave in order to fit with these other individuals.

According to Mead, a person is not only aware of others, but is also able to realize himself. Thus, a person does not only interact with other people (Rismahareni, 2017), but symbolically he also interacts with himself (Haris, 2018). This symbolic-interaction is carried out using language, as the single most important symbol (Pandaleke, 2020). Symbols become important because individuals do not react passively to the reality they experience, but the individual will give meaning to these reactions and will act according to the meaning they give. Humans learn symbols and meanings in social interactions (Shalin, 2020). Through symbols, humans have the ability to stimulate other people in ways that allow them to differ from the stimuli they receive from these other people. In this case Mead distinguishes between natural signs (natural signins) and symbols that contain meaning (significant symbol) (Musnur, 2019). Natural signs are instinctive and cause the same reaction for everyone. For example, water for thirsty people.Significant symbols do not have to cause the same reaction for everyone. Someone who uses a certain symbol gives sickle to the symbol in his mind, but the recipient of the symbol will not necessarily give the symbol the same meaning. Symbolic interactionism is carried out using language, as the only important symbol, and through signs.

George Heber Mead in discussing symbolic interactionism describes the Mind (human mind) as a way of human action that takes place within the individual. This mind is a kind of individual interaction with himself, namely conversation or conservation in his own mind, where one part responds, reviews and even compares what has been stated in other parts. At the same time this mind is always connected with other people. Mind is a process of interaction and part of interaction with other people. Mead's thoughts in general and in particular about the mind (mind) involve his ideas about the importance of self-concept (self), namely the ability of a person to make himself an object and a subject. The self-concept of one's identity arises in the same way. The social environment tells a person that he is a Duko and so on. When conveying it always stimulates a person's individual response. Self relates dialectically to mind, in this case Mead states that the body is not self and will become self when the mind has developed. A common mechanism for self-development is reflectivity or the ability to place oneself unconsciously into another person's place and act as if they are 
acting. So that people are able to examine themselves as other people examine themselves.

From the data above, it can be analyzed using theory George Herbert Mead'sof symbolic interactionism, which is one of the basic principles of this theory, namely the human ability to think. With this thinking ability possessed by humans, this is what distinguishes humans from animals. Thinking according to Mead is a process where individuals interact with themselves by using meaningful symbols. Through the process of interaction with oneself, the individual chooses which of the stimuli aimed at him he will respond to. George Herbert Mead's theory of symbolic interactionism is related Directly to the social interactions that occur between villagers in Rumbia subdistrict make certain considerations if they want to interact with other villagers. This is due to the diversity of cultures in this sub-district. So that it requires a thinking process so that when they interact it does not offend the culture of residents from other villages. By taking into account the social interactions that occur, associativecollaborative interactions can be formed, such as friendships between village adolescents with one another in sub district Rumbia-, mixed marriages, the occurrence of processes trading / trading, following Muslims by participating in a competition in Rumbia District. The ability of this thinking process can also form interactions Associative-Accommodation social, namely an effort made to reduce conflict. Which is when the residents of Restu Buana village and Bumi Nabung Ilir villagers are having a disagreement, the residents Bumi Nabung Ilir prefer to be resolved with kinship, namely by mediation, this is because the residents of Bumi Nabung Ilir village use their thought process before they give real responses to the Restu Buana villagers. The people of Bumi Nabung Ilir took the first consideration so that the conflict would not be prolonged, so that the people of Bumi Nabung Ilir chose to solve the problem through mediation which presented leaders religious as a third party to resolve the problem.

So here, when Restu Buana residents are famous for their actually carok, how do Bumi Nabung Ilir villagers give their responses, they don't face it with carok, but with kinship, so that there will be a common interest to live in harmony together and so on. As well as this thinking process will also form social interactions that occur in the form of dissociative-contravention, such as the response in the form of feelings of dislike given by youth Paseraman to Restu Buana villagers when they carry out social interactions, because the tone of the Restu Buana residents is extra loud and High pitched character is also considered to be extra hard. The ability of this thinking process can also form social interaction dissociative-competitive between villagers in District.

The capacity to think in humans will be formed through a process of social interaction, namely socialization. For symbolic interaction, socialization is dynamic in that in this process, humans not only receive information but also interpret and adapt the information according to their needs. In carrying out social actions an individual usually takes into account other individuals and decides how to behave in order to fit with these other individuals. So that if they match each other with their respective cultures, it creates a form of social interaction that leads to cooperation between one citizen and another. Because here there is an attitude of mutual respect between one culture and another.

The other research, Makmur (2015) found that the social interactions that occur between the villagers also take into account the culture of other villagers when they interact. While, Cahyono (2016) found that the existence of social media has influenced 
social life in society. Changes in social relationships or as changes to the balance (equilibrium) of social relations and all forms of changes in social institutions within a society, which affect the social system, including values, attitudes and behavior patterns among groups in society. Positive social changes such as the ease of obtaining and imparting information, obtaining social and economic benefits. Meanwhile, social changes that tend to be negative, such as the emergence of social groups acting on behalf of religion, ethnicity and certain behavior patterns that sometimes deviate from existing norms (Stephan, et al., 2016; Ahn, et al., 2017). So that they also carry out the socialization process which in the socialization process is done with them making friends, marrying other villagers, in the trade process, living in the same organization. namely the Muslim Koran. So that by mingling and living together with outside the villagers themselves will produce an understanding of how they can live in harmony with other villagers. Because with this socialization, social interaction between residents can be cooperative because they have mutual understanding of each other's cultural conditions. In this socialization, residents in the sub-district can also understand their respective cultures in their interactions because their interactions there is also a learning process for other cultures.

With this socialization, residents also learn about how to respect other cultures outside of their own. So that when they interact with other residents they already understand what they will do in the future. Humans learn symbols and meanings in social interactions. Someone who uses a certain symbol gives meaning to the symbol in his mind, but the recipient of the symbol not will necessarily give the symbol the same meaning. It is meant when a person engages in social interaction between residents of one village and another in this sub-district, which in fact is different in culture and language in particular.

From each villager they give a certain meaning in their mind, and those who receive a symbol will not necessarily give the same meaning. When the villagers of Restu Buana, who in fact speak loudly, then when the villagers of Paseraman interact with the villagers of Restu Buana, they interpret it as something that is not meant as something they want to yell at. But they are like that. Tangkep culture which is defined by the Bumi Nabung Ilir community as a culture that is intended to maintain the morale of these teenagers, is interpreted differently by youths from other villages such as Paseraman, this Tangkep culture means something that is frightening to him as a young man, so this is considered a barrier for him if he is want to interact at his house friend's in Bumi Nabung Ilir village. One of Mead's thoughts besides the ability to think is about self-concept. Which Self relates dialectically to the mind, in this case Mead states that the bodyis not self and will become self when the mind has developed. A common mechanism for self-development is reflectivity or the ability to place oneself unconsciously into person's place another and act as if they are acting. So that people are able to examine themselves as other people examine themselves. This ability to position themselves when viewed from social interactions can be formed when they blend into one among villagers in this sub-district. For example, this is done through marriages mixed between residents of Restu Buana and Bumi Nabung Ilir villages, marriages mixed between residents of Bumi Nabung Ilir, and mixed marriages between residents of Bumi Nabung Ilir village and residents of Restu Buana.

This research in line with Basir et al, (2020) that social interaction does indeed involve a relationship between two or more individuals or groups in a place. It also involves several elements that will govern mutually beneficial interactions such as 
cooperation, conflict, competition, superior and inferior relations (Basir, N., Ab Rahim, I. S., \& Halim, 2020). The elements involved are such as social norms, status and reciprocal resignation (reciprocal obligations) (Haris \& Amalia, 2018). Interaction social is a process involving two or more individuals or groups that involves reciprocal actions, in the sense that one's behavior will take into account and be oriented towards the behavior of another individual.

Othter finding proven that there are many sociological implications in Mead's thought as explained by Najeemah Mohd Yusof (2004) in his paper entitled Sociological Implications of George Herbert Mead's Thought. He explained that socialization has changed human nature to play a role effectively. Social control becomes important and the only necessity is self -control. Social change is more of an original continuous process in human life as a group than an episodic result of unrelated factors in a well -established structure (Amie \& Nuyatin 2014). Human life as a group is more seen as something that is always incomplete and still under construction than moving from a complete state to another state. Social disorder is not seen as a breakdown of existing structures but is seen as an inability to direct action effectively in the face of a given situation. Since social actions affect a person's future, it is considered to have a historical dimension that must be taken into account to provide adequate understanding. Other finding showed that the emergence of social value systems is built through the intersubjectivity between individual interactions and actions. Both are part of the theory of symbolic interactionism, through the use of symbols, both in the form of values, words and social actions, so as to be able to move the social behavior of students when interpreting barakah as a pesantren tradition (Fauzi, 2017). Because for Mead, symbols are the result of the construction of social action based on real life in every interaction, including evoking responses to others. The role is inseparable from the concept of self which is part of the thinking of each individual in building his world. Self -concept is always concerned with emotions, values, skills, intellectuality in the formation of self.

\section{CONCLUSION}

The form of social interaction that occurs between Restu Buana villagers and Bumi Nabung Ilir village residents is in the form of associative-cooperation (in the form of trade / buying and selling between villagers, friendship, marriage between Bumi Nabung Ilir villagers and Bumi Nabung villagers. The same organizational activities that are followed by villagers in sub-district, such as the activities of the recitation Muslimatan, and by participating in competitions held by the sub-district). Second, it is in the form of associative-accommodation (that is, in the event of a fight, usually with mediation by leaders religious, so that the conflict does not last). Third, the form of dissociation $\mathrm{f}$-Contravention which is manifested by the feeling of resentment. Fourth, which is in the form of dissociative-competition such as competition in the economy between wood craftsmen. Factors that support social interaction: first, there is mutual tolerance between residents. Thirdly their mutual appreciation of cultures of other villagers. And factors that hinder the occurrence of social interaction between villagers in District, namely: Lack of knowledge about the culture being faced, so that there can be misunderstandings between villagers. strong that man. This is manifested in the sense that the culture of the group is the most correct. 


\section{ACKNOWLEDGEMENTS}

The authors express our gratitude and appreciation for the trust that has been given by Institut Agama Islam Ma'arif NU Metro Lampung. This research was funded by Institut Agama Islam Ma'arif NU Metro Lampung.

\section{AUTHOR CONTRIBUTION STATEMENTS}

First author had contribution for collecting data in this research. Corresponding author was a corresponding person with editor, from submission until publish for this article. Another authors help to improve this research paper before submit to journal.

\section{REFERENCES}

Abdullah, Siti Nuralfia. "Interaksionisme Simbolik Perempuan Muslim dalam 'Aksi Gejayan Memanggil'."Jurnal Ilmiah Syi'ar 19, no. 2 (2020): 151-167. http://dx.doi.org/10.29300/syr.v19i2.2466

Ayustiani, Hasna, and Lutfi Saksono. "interaksi simbolik tokoh dalam novel demian: die geschichte von emil sinclair jugend karya hermann hesse." IDENTITAET 8, no. 1 (2019). Google Scholar

Ahn, S., Kim, S., \& Zhang, H. (2017). Changes in depressive symptoms among older adults with multiple chronic conditions: Role of positive and negative social support. International journal of environmental research and public health, 14(1), 16. https:// doi.org/10.3390/ijerph14010016

Amie, A. Y., \& Nuryatin, A. (2014). Interaksi Simbolik Tokoh Dewa Dalam Novel Biola Tak Beradawai Karya Seno Gumira Ajidarma: Kajian Interaksionisme Simbolik George Herbert Mead. Jurnal Sastra Indonesia, 3(1). Google Scholar

Basir, N., Ab Rahim, I. S., \& Halim, M. Z. A. (2020). Analisis tingkah laku sosiologi masyarakat berasaskan teori interaksionisme melalui perangkaan data kes COVID-19 di Malaysia. PENDETA: Journal of Malay Language, Education and Literature, 11, 11-30. https:/ / doi.org/10.37134/pendeta.vol11.edisikhas.2.2020

Cahyono, A. S. (2016). Pengaruh media sosial terhadap perubahan sosial masyarakat di Indonesia. Jurnal Publiciana, 9(1), 140-157. Google Scholar

Derung, Teresia Noiman. "interaksionisme simbolik dalam kehidupan bermasyarakat." SAPA-Jurnal Kateketik dan Pastoral 2, no. 1 (2017): 118-131. Google Scholar

Fauzi, A. (2017). Persepsi Barakah di Pondok Pesantren Zainul Hasan Genggong: Studi Interaksionalisme Simbolik. Al-Tahrir: Jurnal Pemikiran Islam, 17(1), 105-132. http:/ / dx.doi.org/10.21154/altahrir.v17i1.848

Haris, Aidil, and Asrinda Amalia."Makna Dan Simbol Dalam Proses Interaksi Sosial (Sebuah Tinjauan Komunikasi)."Jurnal Dakwah Risalah 29, no. 1 (2018): 16-19. http://dx.doi.org/10.24014/jdr.v29i1.5777

Haris, A., \& Amalia, A. (2018). Makna Dan Simbol Dalam Proses Interaksi Sosial (Sebuah Tinjauan Komunikasi). Jurnal Dakwah Risalah, 29(1), 16-19. http:/ / dx.doi.org/10.24014/jdr.v29i1.5777

Hikmah, Hikmah. "Analisis wacana; interaksionisme simbolik."El-Hikam 10, no. 1 (2017): 134-163. Google Scholar

Haris, Aidil, and Asrinda Amalia."Makna Dan Simbol Dalam Proses Interaksi Sosial (Sebuah Tinjauan Komunikasi)."Jurnal Dakwah Risalah 29, no. 1 (2018): 16-19. http:/ / dx.doi.org/10.24014/jdr.v29i1.5777

Ilawatus, Z. "Interaksionisme Simbolik Pekerja Seks Komersial di Karaoke Keluarga X2 Sidoarjo." Paradigma 5, no. 3 (2017). Google Scholar 
Ihsanudin, Ihsanudin. "Polemik" Tulisan Arab" Pada Busana Agnes Monica (Analisis Teori Interaksionisme Simbolik)."Palita: Journal of Social Religion Research 4, no. 1 (2019): 47-60. http:/ / dx.doi.org/10.24256/pal.v4i1.526

Makmur, S. (2015). Budaya hukum dalam masyarakat multikultural. Salam: Jurnal Sosial Dan Budaya Syar-I, 2(2). https:/ / doi.org/10.15408/ sjsbs.v2i2.2387

Musnur, Irfandi. "Analsis Penambahan Fungsi dan Makna Seragam (Jersey) pada Pendukung Club Sepak Bola."Narada 5, no. 1: 111-130. Google Scholar

Mustofa, B. (2017). Interaksi Sosial Warga Perumahan Alam Sejahtera Dedy Jaya Kelurahan Pasarbatang Kabupaten Brebes. Unnes Civic Education Journal, 3(2). Google Scholar

Najeemah Mohd Yusof (2004). Implikasi Sosiologi Pemikiran George Herbert Mead.Jurnal Pendidik dan Pendidikan, 19,139-157. Google Scholar

Pandaleke, Tommy Frans, Ferry VIA Koagouw, and Grace J. Waleleng. "Peran Komunikasi Sosial Masyarakat Dalam Melestarikan Bahasa Daerah Pasan Di Desa Rasi Kecamatan Ratahan Kabupaten Minahasa Tenggara."ACTA DIURNA KOMUNIKASI 2, no. 3 (2020). Google Schoolar

Result Interview Ruli, at Restu Buana, 06 November 2020

Result Interview the community, at Bumi Nabung Ilir, 06 November 2020.

Rismahareni, Ayu, Sucipto Sucipto, and Haerussaleh Haerussaleh."Kajian Interaksionisme Simbolik Kidung Jula Juli pada Pementasan Ludruk Irama Budaya Surabaya."Jurnal Ilmiah FONEMA: Jurnal Edukasi Bahasa dan Sastra Indonesia 4, no. 2 (2017). Google Scholar

Shalin, Dmitri N. "Norbert Elias, George Herbert Mead, and the Promise of Embodied Sociology." The American Sociologist (2020): 1-19.

Saputra, Johan Effendy Dwi. "interaksi sosial antara difabel dengan pedagang pasar tanggul di kota surakarta." Jurnal Analisa Sosiologi 9. Google Scholar

Stephan, U., Patterson, M., Kelly, C., \& Mair, J. (2016). Organizations driving positive social change: A review and an integrative framework of change processes. $\begin{array}{llll}\text { Journal of } & \text { Management, }\end{array}$ https:// doi.org/10.1177\%2F0149206316633268

Tamboeo, G., Waani, J. O., \& Tilaar, S. (2016). Dampak Sosial dari Pola Perumahan Permata Asri Pineleng. SPASIAL, 3(1), 46-54. Google Scholar

Yuliati, anita. "Identifikasi Interaksi Sosial Lansia Penghuni Liponsos."Paradigma 5, no. 3 (2017). Google Scholar

Wilson, D. K., Sweeney, A. M., Kitzman-Ulrich, H., Gause, H., \& George, S. M. S. (2017). Promoting social nurturance and positive social environments to reduce obesity in high-risk youth. Clinical child and family psychology review, 20(1), 64-77. https:// doi.org/10.1007/s10567-017-0230-9

Copyright Holder :

(C) Rohmawati, A., Trihastuti, M., Suryaningsih, A \& Ismail, H. (2021).

First Publication Right :

(C) IJoASER (International Journal on Advanced Science, Education, and Religion)

This article is under:

CC BY SA 